\title{
Higher surface ozone concentrations over the Chesapeake Bay than over the adjacent land: Observations and models from the DISCOVER-AQ and CBODAQ campaigns
}

Daniel L. Goldberg ${ }^{\mathrm{a}, *}$, Christopher P. Loughner ${ }^{\mathrm{b}, \mathrm{c}}$, Maria Tzortziou ${ }^{\mathrm{b}, \mathrm{c}}$, Jeffrey W. Stehr ${ }^{\mathrm{a}}$, Kenneth E. Pickering ${ }^{\text {a,c }}$, Lackson T. Marufu ${ }^{a}$, Russell R. Dickerson ${ }^{a}$

${ }^{a}$ Department of Atmospheric and Oceanic Science, University of Maryland, College Park, MD 20742, USA

${ }^{\mathrm{b}}$ Earth System Science Interdisciplinary Center, University of Maryland, College Park, MD 20740, USA

${ }^{\mathrm{c}}$ NASA Goddard Space Flight Center, Greenbelt, MD 20771, USA

\section{H I G H L I G H T S}

- Observations of ozone are higher over the Chesapeake Bay than areas upwind on land.

- Dry deposition rates, boundary layer depth, and photolysis play an integral role.

- Model resolution plays a role in determining accurate surface ozone concentrations.

- Observations of total reactive nitrogen are much lower than model simulations.

\section{A R T I C L E I N F O}

\section{Article history:}

Received 10 May 2013

Received in revised form

1 October 2013

Accepted 4 November 2013

\section{Keywords:}

Ozone

Total reactive nitrogen

Chesapeake Bay

Community multiscale air quality (CMAQ)

model

\begin{abstract}
A B S T R A C T
Air quality models, such as the Community Multiscale Air Quality (CMAQ) model, indicate decidedly higher ozone near the surface of large interior water bodies, such as the Great Lakes and Chesapeake Bay. In order to test the validity of the model output, we performed surface measurements of ozone $\left(\mathrm{O}_{3}\right)$ and total reactive nitrogen $\left(\mathrm{NO}_{y}\right)$ on the 26-m Delaware II NOAA Small Research Vessel experimental (SRVx), deployed in the Chesapeake Bay for 10 daytime cruises in July 2011 as part of NASA's GEO-CAPE CBODAQ oceanographic field campaign in conjunction with NASA'S DISCOVER-AQ air quality field campaign. During this 10 -day period, the EPA $\mathrm{O}_{3}$ regulatory standard of 75 ppbv averaged over an 8-h period was exceeded four times over water while ground stations in the area only exceeded the standard at most twice. This suggests that on days when the Baltimore/Washington region is in compliance with the EPA standard, air quality over the Chesapeake Bay might exceed the EPA standard. Ozone observations over the bay during the afternoon were consistently 10-20\% higher than the closest upwind ground sites during the 10-day campaign; this pattern persisted during good and poor air quality days. A lower boundary layer, reduced cloud cover, slower dry deposition rates, and other lesser mechanisms, contribute to the local maximum of ozone over the Chesapeake Bay. Observations from this campaign were compared to a CMAQ simulation at $1.33 \mathrm{~km}$ resolution. The model is able to predict the regional maximum of ozone over the Chesapeake Bay accurately, but $\mathrm{NO}_{y}$ concentrations are significantly overestimated. Explanations for the overestimation of $\mathrm{NO}_{y}$ in the model simulations are also explored.
\end{abstract}

(c) 2013 Elsevier Ltd. All rights reserved.

\section{Introduction}

Surface ozone, in high enough concentrations, is a hazardous secondary air pollutant regulated by the United States Environmental Protection Agency (U.S. EPA). As of 2013, the U.S. EPA has set an ambient 8-h daily maximum concentration of 75 parts per

\footnotetext{
* Corresponding author. Tel.: +1 8604246851.

E-mail address: dgoldb@atmos.umd.edu (D.L. Goldberg).
}

billion by volume (ppbv) under the National Ambient Air Quality Standards (NAAQS). This standard has been set based on several health studies (Anenberg et al., 2010; Bell et al., 2004; Fann et al., 2011) that show inhaling ozone can lead to premature aging of the lungs, difficulty breathing, increased risk of asthma attacks, and in rare cases death. Reactive nitrogen species and volatile organic compounds, emitted by natural and anthropogenic sources, react photochemically to create ozone (Seinfeld and Pandis, 2006). Warm temperatures, along with a capping inversion, associated 
with a strong summer anticyclone aid in the rapid growth of ozone near the surface during the late morning and early afternoon.

Air quality models such as the Community Multiscale Air Quality (CMAQ) model indicate decidedly higher ozone near the surface of large interior waters bodies such as the Great Lakes and Chesapeake Bay (e. g., Godowitch et al., 2008). In order to test the validity of the model output, we performed surface measurements of ozone $\left(\mathrm{O}_{3}\right)$ and total reactive nitrogen $\left(\mathrm{NO}_{y}\right)$ on 26 -m Delaware II NOAA Small Research Vessel experimental (SRVx), deployed in the Chesapeake Bay for ten daytime cruises in July 2011. The objectives of this paper are to:

- Compare ozone observations over the Bay to nearby land areas

- Determine if ozone concentrations are indeed higher over the Bay

- Determine if known meteorological and chemical processes can explain the observed differences

- Investigate whether model grid resolution plays a role in determining the simulated surface ozone concentrations over the Bay

- Investigate $\mathrm{NO}_{y}$ observations to determine if this group of precursors is accurately predicted by the model simulations

\subsection{Current EPA regulations and designations}

The U.S. EPA has designated a "moderate" non-attainment region in the counties surrounding Baltimore, MD and a "marginal" non-attainment region throughout the New York CityPhiladelphia-Washington, D.C. metropolitan corridor (U.S. EPA, 2008). A "moderate" attainment region is an area that has a ground station that exceeds an 8-h maximum concentration of $85 \mathrm{ppbv} \mathrm{O}_{3}$ in its 3rd highest day, while a marginal attainment region has a threshold of 75 ppbv.

The Baltimore/Washington metropolitan region exceeds the threshold due to favorable meteorological conditions for ozone production during the summer months and substantial ozone precursor emissions, generated locally as well as advected to the region during strong westerly transport conditions (Ryan et al., 1998; He et al., 2013). Peaks in surface ozone are highest just downwind of major metropolitan areas due to the enhanced emissions from the metropolitan city centers (Kleinman et al., 2000). This has been shown in many air quality model simulations (Yegorova et al., 2011; Castellanos et al., 2011) and has been verified by ground monitoring stations (U.S. EPA, 2006; Castellanos et al., 2009). In the Baltimore-Washington region there are complex interactions that arise with the influence of the Chesapeake Bay breeze (Loughner et al., 2011; Stauffer et al., 2012), which have not been fully investigated.

\subsection{Previous field campaigns over interior water bodies}

Measurements of ozone over the southern Great Lakes during a 2007 summer field campaign show higher concentrations of ozone over the lakes than over the adjacent land with the biggest difference detected at night (Levy et al., 2010). A similar study was conducted over Lake Michigan in the summers of 1990 and 1991, where $\mathrm{O}_{3}$ and $\mathrm{NO}_{x}$ were monitored from aircraft (Luria et al., 1992). High levels of ozone are shown only at the lowest levels of the boundary layer, which they attribute to a lack of vertical mixing over the lake (Dye et al., 1995). An experiment in 2003 measured ozone at the Chesapeake Bay Lighthouse, located on an island 15 miles to the east of the entrance to the Chesapeake Bay, as a means to test ozone monitoring on ocean buoys and towers (Hintsa et al., 2004). This field campaign found ozone at the surface consistently exceeding 80 ppbv during an air quality episode from June 24 to 28 , 2003.

\subsection{DISCOVER-AQ And GEO-CAPE CBODAQ field campaigns}

During the month of July 2011, the National Aeronautics and Space Administration (NASA) conducted a comprehensive air quality field study, DISCOVER-AQ (Crawford and Pickering, 2011), in the Washington, DC-Baltimore, MD metropolitan area and over the Chesapeake Bay to investigate air quality with the primary goal of providing data to better interpret observations from current and future satellites for air quality applications. In conjunction with DISCOVER-AQ, NASA conducted the oceanographic field campaign GEO-CAPE CBODAQ (Geostationary Coastal and Air Pollution Events-Chesapeake Bay Oceanographic Campaign with DISCOVER$\mathrm{AQ})$, to address questions related to both estuarine biogeochemical processes as well as atmospheric pollution over the Chesapeake Bay urban estuarine environment (Tzortziou et al., 2013). There were seven instrument platforms during the field campaign. A detailed description of the modes, locations, types, and days of observations is provided in Table 1 . This paper focuses on observations from the $26 \mathrm{~m}$ Delaware II NOAA Small Research Vessel experimental (SRVx) deployed in the Chesapeake Bay as part of the CBODAQ campaign from July 11 to 20, 2011.

\section{Materials and methods}

\subsection{Measurements description}

The SRVx was equipped with a Thermo Environmental Model 49 UV photometric ozone $\left(\mathrm{O}_{3}\right)$ analyzer and a modified Thermo Environmental Model 42C chemiluminescence nitric oxide (NO) analyzer retrofitted with an external molybdenum catalyst to also measure total reactive nitrogen $\left(\mathrm{NO}_{y}\right)$ (Delany et al., 1982). The $\mathrm{NO}_{y}$ analyzer was zeroed for 10 min each hour during the campaign and

Table 1

Modes of measurement during Phase I of the DISCOVER-AQ campaign in the Baltimore-Washington region.

\begin{tabular}{|c|c|c|c|}
\hline Mode of measurement & Trace gases measured & Location & $\begin{array}{l}\text { Days in which Active during } \\
\text { July } 11,2011 \text { through July } 20,2011\end{array}$ \\
\hline NASA P3-B & $\begin{array}{l}\mathrm{O}_{3}, \mathrm{NO}, \mathrm{NO}_{2}, \mathrm{PNs}, \mathrm{ANs}, \mathrm{HNO}_{3} \\
\mathrm{NO}_{y}, \mathrm{CO}, \mathrm{CH}_{4}, \mathrm{CH}_{2} \mathrm{O}, \mathrm{CO}_{2}, \mathrm{VOCs}\end{array}$ & & July 11 , July 14 , July 16 , July 20 \\
\hline UC-12 king air & Column $\mathrm{O}_{3}, \mathrm{NO}_{2}, \mathrm{CH}_{2} \mathrm{O}$ & & July 11 , July 14 , July 20 \\
\hline Cessna 402B & $\mathrm{O}_{3}, \mathrm{SO}_{2}, \mathrm{CO}, \mathrm{NO}_{2}$ & & July 11 , July 18 , July 20 \\
\hline MDE ground stations & $\mathrm{O}_{3}, \mathrm{NO}, \mathrm{NO}_{y}, \mathrm{PM} 2.5, \mathrm{CO}, \mathrm{SO}_{2}$ & $\begin{array}{l}\text { Aldino, MD, Beltsville, MD, Edgewood, MD, } \\
\text { Essex, MD, Fairhill, MD, Padonia, MD }\end{array}$ & Every day \\
\hline Pandora & Column $\mathrm{NO}_{2}$ & $\begin{array}{l}\text { Aldino, MD, Beltsville, MD, Edgewood, MD, } \\
\text { Essex, MD, Fairhill, MD, Padonia, MD, } \\
\text { College Park, MD, Catonsville, MD, SRVx NOAA Vessel }\end{array}$ & Every day \\
\hline Ozonesondes & $\mathrm{O}_{3}$ & Edgewood, MD & Every day \\
\hline SRVx NOAA research vessel & $\mathrm{O}_{3}, \mathrm{NO}$, total $\mathrm{NO}_{y}$ & See Fig. 1 & Every day \\
\hline
\end{tabular}


measurements were adjusted based on the drift of the instrument. The $\mathrm{NO}_{y}$ analyzer was calibrated in-situ on July 19, 2011 using a $\mathrm{NO}_{2}$ standard reference material (SRM) from the National Institute of Standards and Technology (NIST).

\subsection{Model description}

In this study, we use U.S. EPA's Community Multiscale Air Quality (CMAQ) (Byun and Schere, 2006) model Version 5.0, driven off-line by output from the Weather Research and Forecasting (WRF) (Skamarock et al., 2008) model Version 3.3 to simulate the state of the atmosphere covering the entire months of June and July 2011. Passing the meteorology into an air quality model at a high temporal resolution or running the chemistry online within a meteorological model is preferable, but requires significantly more computational resources (Grell et al., 2004).

The WRF and CMAQ model simulations are at $36,12,4 \& 1.33 \mathrm{~km}$ resolution in the area of interest with 34 verticals levels from the surface to 100 mbar and 16 levels within the lowest $2 \mathrm{~km}$ in order to accurately simulate boundary layer processes. The $1.33 \mathrm{~km}$ model domain covers the Baltimore-Washington metropolitan region and nearby Chesapeake Bay. The North American Regional Reanalysis (NARR) is used for the model initial and outermost lateral boundary conditions in WRF. The Multi-scale Ultra-High Resolution (MUR) dataset was used to set the sea surface temperatures. The WRF model was re-initialized every 3 days and run in 3.5 day increments. The first $12 \mathrm{~h}$ of each simulation was thrown out (i.e., not passed to CMAQ). WRF model output is input into the Meteorology-Chemistry Interface Processor (MCIP; Otte and Pleim, 2010) to create meteorological input fields for CMAQ. Chemical initial and boundary conditions come from a MOZART-4 simulation (Emmons et al., 2010). The Carbon-Bond-05 (CB05) gas-phase chemical mechanism (Yarwood et al., 2005) was used in CMAQ. The CMAQ and WRF simulations began May 24, 2011, which allows ample spin-up time for our comparison in mid-July.

Anthropogenic emissions input files for CMAQ are created with the Sparse Matrix Operator Kernel Emissions (SMOKE) modeling system (Houyoux and Vukovich, 1999). We use a projected 2012 emissions inventory because a 2011 emissions inventory is not yet available. Annual projected point and countywide area emissions are temporally distributed based on the time of day, day of the week, and season based on temporal surrogates from the EPA. Mobile emissions estimates from cars, trucks, and motorcycles are computed with the Motor Vehicle Emission Simulator (MOVES; Kota et al., 2012). Point sources are vertically distributed based on the meteorology, stack height, and the temperature and velocity of the emissions exiting the stack. Biogenic emissions are calculated using Biogenic Emissions Inventory System (BEIS) and lightning $\mathrm{NO}_{x}$ emissions are calculated in-line within the CMAQ model. Further model details on the parameterization options are described in the Supplementary Material.

\section{Results}

\subsection{Observational comparisons: ozone}

The SRVx was deployed in the Chesapeake Bay for 10 daytime cruises during the DISCOVER-AQ Maryland campaign extending from July 11, 2011 through July 20, 2011. This overlapped with four flights of the NASA P3-B (a four-engine turboprop capable of long duration flights of $8-12 \mathrm{~h}$ ) three flight days (2 flights per day) of the UC-12B King Air (a twin-engine turboprop capable of $6 \mathrm{~h}$ flights) and three flight days ( 2 flights per day) of the University of Maryland (UMD) Cessna 402B (a twin-piston engine, unpressurized aircraft) (Table 1). The SRVx docked each night in Annapolis, MD and had different cruise route each day (Fig. 1). The instruments were running while the SRVx was in port overnight in Annapolis, $\mathrm{MD}$, but the data are subject to frequent local emissions.

A time series of $\mathrm{O}_{3}$ for the 10-day period can be seen in Fig. 2. On four days ozone exceeded the 8-h maximum 75 ppbv NAAQS threshold on the moving vessel in the Chesapeake Bay: July 12, 13, $19 \& 20$. During this same time period, ground stations in the DISCOVER-AQ field campaign region (stations denoted in Table 2) exceeded the $75 \mathrm{ppbv}$ threshold an average of 0.71 times per ground station. This alone is an indicator that the ozone may be higher near the surface of the Chesapeake Bay than nearby ground stations.

Comparing the hourly ozone at the SRVx's location and closest upwind ground station reinforces the idea that higher ozone concentrations exist over the Bay. The closest upwind ground station was determined by using the backward trajectories at $10 \mathrm{~m}, 500 \mathrm{~m}$, $1500 \mathrm{~m}$ heights ending at 1800 UTC (2 PM local time) using Global Data Assimilation System (GDAS) meteorological data in the NOAA HYSPLIT trajectory model (Draxler and Rolph, 2003). Eight-hour maximum ozone from all relevant ground sites and the SRVx can be seen in Table 2. The closest upwind ground station was often only 20-30 km away and was chosen to ensure that comparisons were made following the same parcel of air. Fig. 3a and $b$ shows that during an exceedance day (July 13) and non-exceedance day (July 14) on the boat, the ozone near the surface of the Chesapeake Bay is uniformly higher. During the afternoon of July 13 the ozone measurement on the SRVx was $10-40$ ppbv greater than at the Calvert County MDE site. Ozone was consistently 10-20 ppbv greater over the Bay than at the Essex MDE site throughout the day on July 14.

The 8-h maximum ozone concentration over the Bay during each day of the 10-day cruise averaged $12.7 \pm 6.1$ ppbv higher than the closest upwind ground site. The systematic high anomaly over the Chesapeake Bay can be seen in Fig. 4. The closest upwind ground site never experienced higher 8 -h maximum ozone and

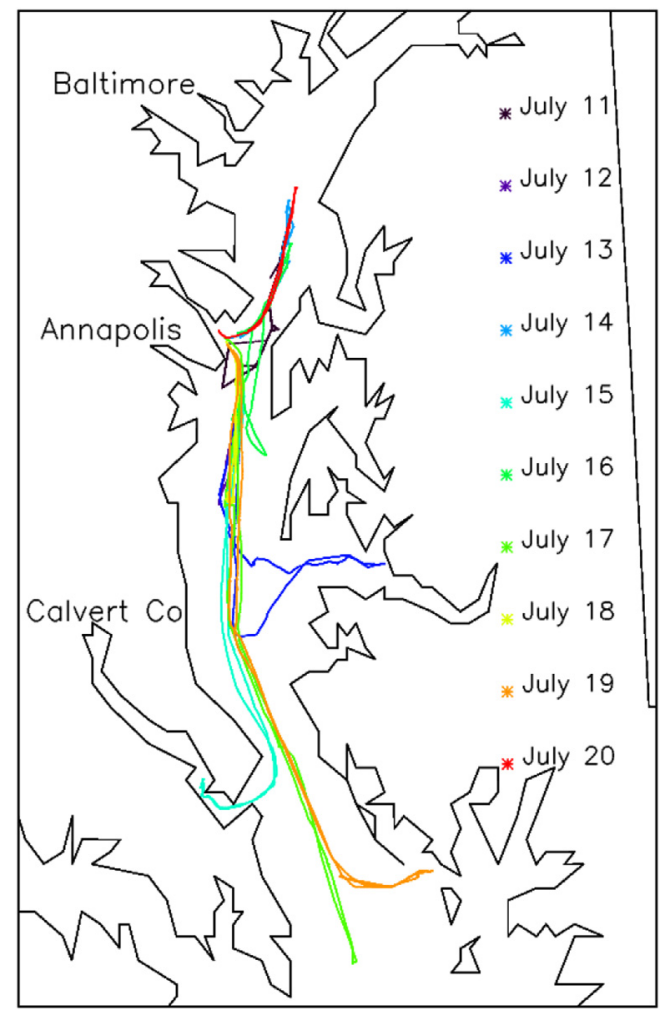

Fig. 1. Map of NOAA Delaware II SRVx routes from July, 11, 2011 through July 20, 2011. 


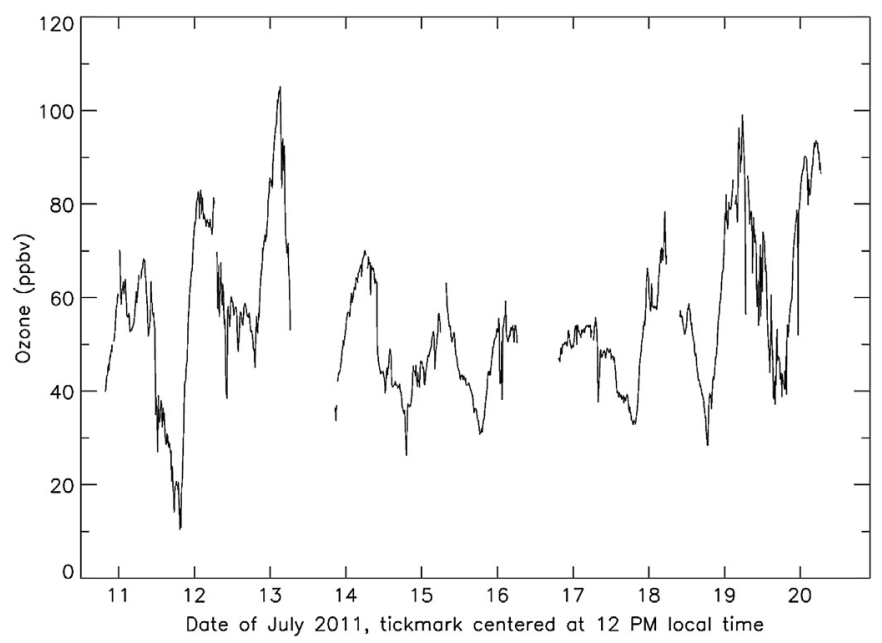

Fig. 2. Ozone concentration (ppbv) as a function of time from July 11, 2011 through July 20, 2011. Map routes for each specific day can be seen in Fig. 1. From 7 PM until 6 AM local time, the boat was docked at the US Naval Academy in Annapolis, MD.

only during three days did any ground station in the region have an 8-h maximum ozone concentration that was 10 ppbv higher than the SRVx's location. This was especially pronounced on July 13 when the SRVx saw an 8-h maximum of 85 ppbv and none of the ground stations in the region exceeded the 75 ppbv NAAQS standard. When compared to 8-h maximum ozone at the ground stations in the Baltimore "moderate" non-attainment area, the 8h ozone at the SRVx's location was $4.6 \pm 14.3$ ppbv higher suggesting that the Chesapeake Bay has just as poor if not worse air quality than the surrounding "moderate" non-attainment area.

The ozone concentration remained higher over the Chesapeake Bay later into the afternoon than over the ground stations, suggesting that there must be a mechanism to maintain high $\mathrm{O}_{3}$ concentrations later into the day. A plot of the median hourly ozone concentrations at the SRVx's location and closest upwind ground station (Fig. 5) illustrates the late afternoon high anomaly. Ozone concentrations over the Bay are greater and exist for longer durations than over the upwind land area due to several potential causes:

(1) A difference in ozone deposition rates over land and water;

(2) A shallower PBL depth over the Chesapeake Bay than the nearby land causing emissions from shipping to be trapped near the surface;

(3) Fewer fair-weather cumulus clouds over the Chesapeake Bay allowing for increased photolysis; and
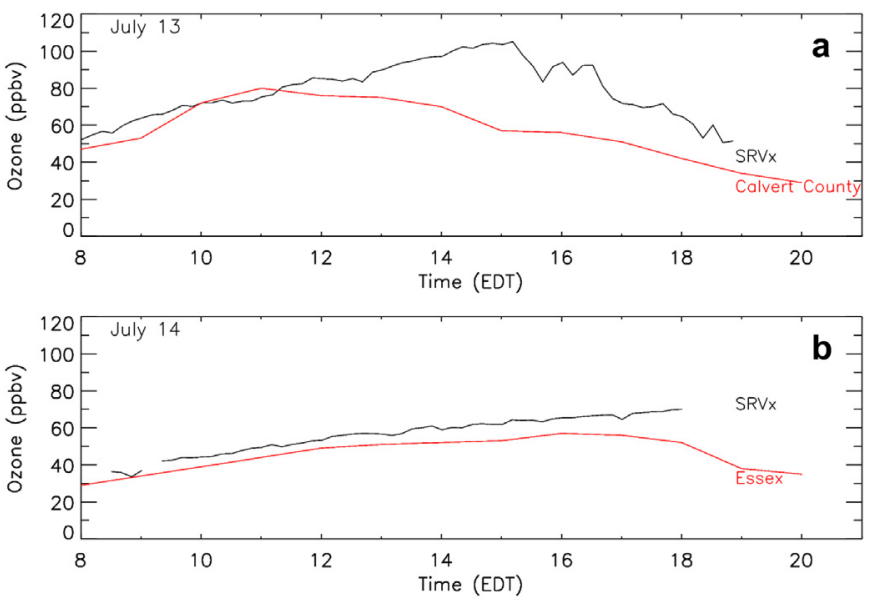

Fig. 3. a. Ozone concentration on July 13, 2011 (ppbv) as a function of time at the SRVx's location and the Calvert County ground monitoring station, the closest upwind monitoring station. b. Same as Fig. 3a but on July 14, 2011 Essex was the closest upwind monitoring station.

(4) Decreased boundary layer venting caused by a meso-high pressure that develops over the Bay as part of the baybreeze circulation trapping pollutants.

Furthermore, when meteorological conditions are conducive, a low-level jet can form overnight transporting polluted air over the Chesapeake Bay from the Norfolk/Virginia Beach, VA metropolitan region bypassing ground stations allowing for increased ozone production over the Bay. This phenomenon, however, was not observed during this field campaign.

\subsection{Model comparisons: ozone}

Our CMAQ model simulation results typically reproduce the systematically higher ozone concentrations over the Chesapeake Bay than in the Baltimore-Washington region. As shown in Fig. 6, median ozone concentrations for the 10-day period output by both the $1.33 \mathrm{~km}$ and $4 \mathrm{~km}$ resolution CMAQ model simulations closely match the observations from the SRVx throughout the day. Model mean bias of ozone at the boat's location was $0.78 \mathrm{ppbv}$, but a rootmean square error (RMSE) of 10.14 ppbv Table 3 shows the mean model bias, normalized mean bias, root-mean square error, and normalized mean error. At a grid cell size of $12 \mathrm{~km}$, the surface ozone output by the model begins to lose correlation and at a grid cell size of $36 \mathrm{~km}$, there was very little correlation throughout the

Table 2

Maximum $8 \mathrm{~h}$ ozone at various sites in the Maryland \& Delaware region.

\begin{tabular}{|c|c|c|c|c|c|c|c|c|c|c|}
\hline Site name & $7 / 11 / 11$ & $7 / 12 / 11$ & $7 / 13 / 11$ & $7 / 14 / 11$ & $7 / 15 / 11$ & $7 / 16 / 11$ & $7 / 17 / 11$ & $7 / 18 / 11$ & $7 / 19 / 11$ & $7 / 20 / 11$ \\
\hline SRVx Boat & 58 & 77 & 85 & 60 & 50 & 51 & 52 & 66 & 80 & 86 \\
\hline Aldino & 69 & 66 & 56 & 51 & 70 & 59 & 61 & 88 & 73 & 77 \\
\hline Calvert Co. & 58 & 71 & 67 & 49 & 38 & 37 & 40 & 57 & 66 & 59 \\
\hline Davidsonville & 53 & 67 & 61 & 50 & 45 & 41 & 41 & 81 & 76 & 63 \\
\hline Edgewood & 61 & 61 & 52 & 49 & 66 & 55 & 53 & 82 & 59 & 74 \\
\hline Essex & 58 & 61 & 53 & 51 & 58 & 47 & 51 & 71 & 72 & 68 \\
\hline Fairhill & 68 & 65 & 49 & 48 & 69 & 51 & 55 & 86 & 68 & 66 \\
\hline HU-Beltsville & 75 & 63 & 59 & 61 & 52 & 49 & 54 & 75 & 60 & 80 \\
\hline Millington & 59 & 68 & 58 & 54 & 59 & 46 & 47 & 62 & 68 & 68 \\
\hline Padonia & 73 & 64 & 54 & 52 & 62 & 60 & 53 & 67 & 65 & 86 \\
\hline PG Equestrian & 54 & 72 & 62 & 51 & 44 & 42 & 41 & 80 & 75 & 61 \\
\hline South Maryland & 55 & 70 & 63 & 46 & 40 & 38 & 42 & 54 & 64 & 71 \\
\hline Lums Pond, DE & 59 & 65 & 53 & 49 & 58 & N/A & 49 & 76 & 61 & 57 \\
\hline Seaford, DE & 53 & 76 & 62 & 44 & 46 & $\mathrm{~N} / \mathrm{A}$ & 41 & 52 & 63 & 65 \\
\hline Closest ground site & 58 & 67 & 62 & 49 & 38 & 37 & 40 & 54 & 64 & 68 \\
\hline Name of closest ground site & Calvert & Davidsonville & PG Equestrian & Lums Pond & Calvert & Calvert & Calvert & S Maryland & S Maryland & Millington \\
\hline
\end{tabular}




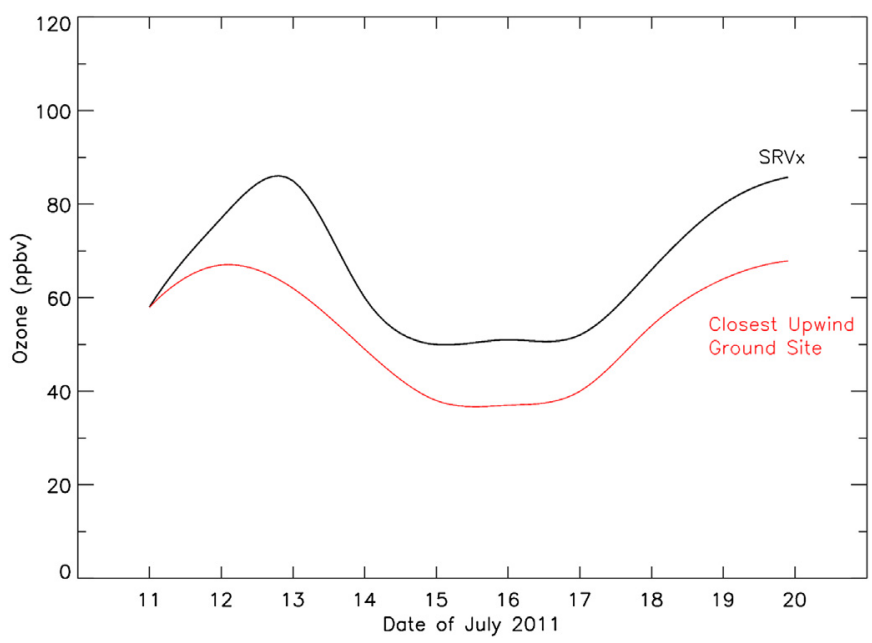

Fig. 4. 8-h maximum ozone concentrations (ppbv) at the SRVx's location and the closest upwind ground monitoring station from July 11, 2011 through July 20, 2011.

day; both the $12 \mathrm{~km}$ and $36 \mathrm{~km}$ model runs show a high model bias in the late morning and afternoon. Model resolution seems to play an integral role in predicting ozone concentrations over the Bay.

Furthermore, we conducted a validation of the 2-m temperature in the $1.33 \mathrm{~km}$ WRF model simulation to ensure that the meteorology is indeed representative of the actual conditions during the 10-day period. Model mean bias of 2-m temperature at the boat's location over the 10 -day period was $-0.52{ }^{\circ} \mathrm{C}$ and a RMSE of $1.59{ }^{\circ} \mathrm{C}$, which was a lower error than the nearby BWI airport. Table 4 shows the hourly mean model bias and RMSE at the boat's location and the BWI airport. WRF at 1.33 and $4 \mathrm{~km}$ resolution was able to reasonably capture wind speed and direction. For example, on July 20 the boat showed light winds that veered dramatically from the NE to SW at 1 PM local time. The WRF runs at both resolutions indicated a similar wind shift but closer to 4 PM local time. This will shift the ozone maximum by only a few hours.

Although the $1.33 \mathrm{~km}$ resolution CMAQ model simulation closely matched the median for the 10-day period, on certain days the model was unable to predict ozone accurately, with a high bias shown in Fig. 7a and a low bias shown in Fig. 7b. During an exceedance day (July 12), the model had a consistent 10-15 ppbv high

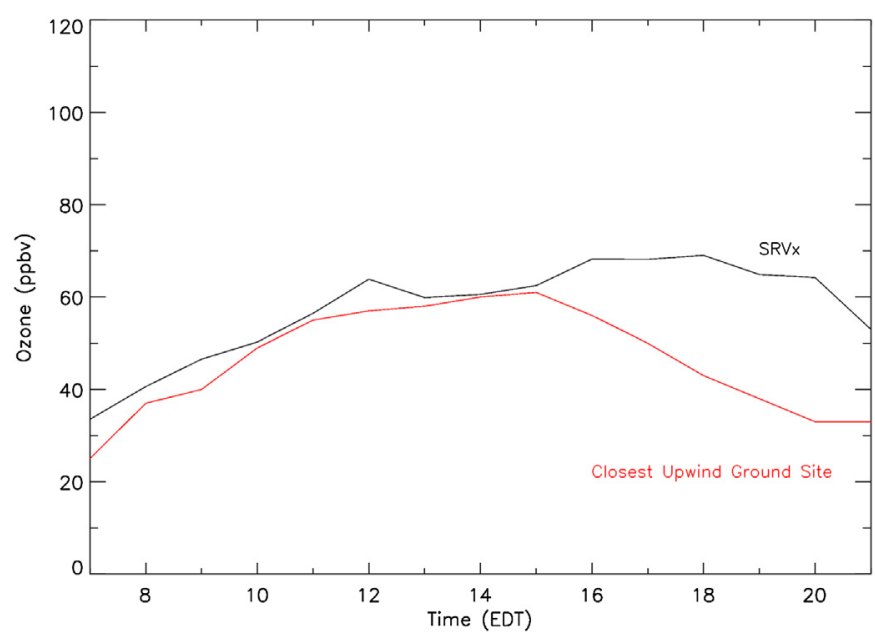

Fig. 5. Median hourly ozone concentrations (ppbv) at the SRVx's location and the closest upwind ground monitoring station from July 11, 2011 through July 20, 2011 as a function of time.

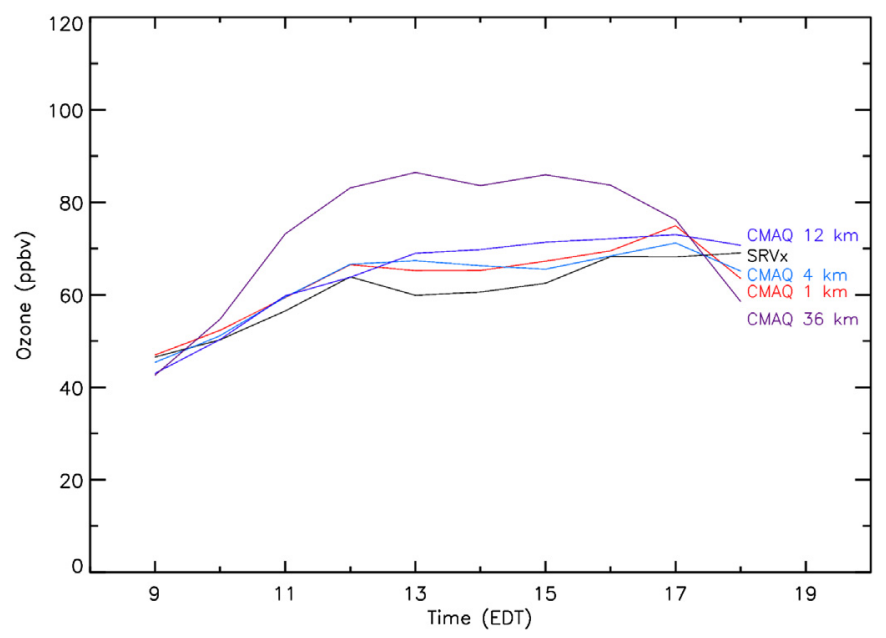

Fig. 6. Median ozone concentrations (ppbv) at the SRVx's location and at the closest CMAQ (1.33 km) grid point for each hour from July 11, 2011 through July 20, 2011 as a function of time.

bias and on an earlier exceedance day (July 13), the model had a 10-15 ppbv low bias. The high bias of the model can likely be attributed to the boundary layer depths calculated by WRF and input into CMAQ, while the low bias of the model may be related to a lower temperature at the surface or perhaps a more stratified PBL inhibiting downward mixing.

Measurements of the aerosol-based boundary layer height were determined by a High Spectral Resolution Lidar (HSRL) instrument onboard the UC-12B aircraft on July 20. The HSRL dataset includes aerosol extinction at $532 \mathrm{~nm}$, aerosol backscatter at $532 \mathrm{~nm}$ and $1064 \mathrm{~nm}$ and depolarization at $532 \mathrm{~nm}$ and $1064 \mathrm{~nm}$ (Hair et al., 2008) and profiles of aerosol backscatter are used to derive the mixed layer height (Scarino et al., 2013). Observations from the HSRL were compared to the modeled boundary layer from WRF on July 20. Observations were used only for July 20 because this was the only day the SRVx was in the north part of the Chesapeake Bay and the UC-12B aircraft simultaneously conducted a flight. On July 20 , the modeled boundary layer in the morning agreed to within $100 \mathrm{~m}$, but in the afternoon the modeled boundary layer was 300-500 m lower over the Chesapeake Bay than the observed aerosol-based boundary layer (Fig. 8).

\subsection{Observational comparisons: total reactive nitrogen}

Observations of reactive nitrogen species are critical since the eastern United States lies in the $\mathrm{NO}_{x}$-limited regime of ozone

Table 3

CMAQ model mean bias (model minus observations), normalized mean bias, rootmean square error (RMSE), and normalized mean error (NME) of ozone (ppbv) for the boat and nearby ground stations.

\begin{tabular}{lcccc}
\hline Location & Mean bias (ppbv) & $\begin{array}{l}\text { Normalized } \\
\text { mean bias (\%) }\end{array}$ & RMSE (ppbv) & NME (\%) \\
\hline SRVx boat & -0.78 & -1.55 & 10.14 & 20.23 \\
Southern MD & 5.00 & 9.98 & 10.69 & 21.33 \\
Calvert County & 4.89 & 9.77 & 10.06 & 20.08 \\
Seaford, DE & 2.76 & 5.51 & 9.64 & 19.24 \\
PG Equestrian & 0.79 & 1.57 & 11.87 & 23.68 \\
Davidsonville & 2.24 & 4.47 & 12.21 & 24.35 \\
Beltsville & 1.60 & 3.20 & 10.52 & 20.99 \\
Essex & 1.67 & 3.33 & 9.84 & 19.63 \\
Edgewood & -1.96 & -3.91 & 11.05 & 22.05 \\
Millington & 0.22 & 0.44 & 9.94 & 19.84 \\
Lums Pond, DE & 1.77 & 3.53 & 12.40 & 24.75 \\
\hline
\end{tabular}


Table 4

WRF model mean bias, max difference, and root-mean square error of $2 \mathrm{~m}$ temperature $\left({ }^{\circ} \mathrm{C}\right)$ for the boat and BWI airport.

\begin{tabular}{llll}
\hline Location & Mean bias $\left({ }^{\circ} \mathrm{C}\right)$ & Max difference $\left({ }^{\circ} \mathrm{C}\right)$ & $\operatorname{RMSE}\left({ }^{\circ} \mathrm{C}\right)$ \\
\hline SRVx boat & -0.52 & 4.62 & 1.59 \\
BWI airport & 1.24 & 4.20 & 2.35 \\
\hline
\end{tabular}

production (Chameides et al., 1992; Trainer et al., 1993; Frost et al., 2006) due to the excess of largely biogenic isoprene. Accurate model output of $\mathrm{NO}_{y}$ species is especially important due to reactive nitrogen's critical role in ozone formation in the $\mathrm{NO}_{x}$-limited regime found in eastern United States during the summer.

Observations from the SRVx were compared to the UC-Berkeley thermal dissociation laser-induced fluorescence (TD-LIF) instrument (Day et al., 2002) used on the P3-B when it flew spirals over the Chesapeake Bay. The TD-LIF does not measure NO, so all comparisons are $\mathrm{NO}_{y}-\mathrm{NO}$. The observations of $\mathrm{NO}_{y}-\mathrm{NO}$ from the SRVx using a chemiluminescence instrument with external molybdenum converter are higher than the data from the TD-LIF. This is an expected outcome since $\mathrm{NO}_{y}$ concentrations decrease exponentially with height (Brent et al., 2013) due to emissions that come from the surface and relatively short lifetimes compared to other trace gases. There were no other suitable ground observations of $\mathrm{NO}_{y}$ during this campaign.

\subsection{Model comparisons: total reactive nitrogen}

Observations of $\mathrm{NO}_{y}$ from the SRVx were compared to $1.33 \mathrm{~km}$ CMAQ results over the Bay. On each day of the 10 daytime cruises, with the exception of July 19 when the instrument was taken offline for calibration, $\mathrm{NO}_{y}$ observations were consistently lower than the output from the nearest grid point in CMAQ. The model regularly overestimated $\mathrm{NO}_{y}$ and on July 12 , it was overestimated by $100 \%$ in the mid-afternoon as shown in Fig. 9 . The data from the TD-LIF instrument (Day et al., 2002) on the P3-B aircraft during a spiral on July 20 also indicate a significant overestimation of $\mathrm{NO}_{y}$ species by CMAQ as shown in Fig. 10. While the vertical profiles of $\mathrm{NO}_{2}$ and $\mathrm{HNO}_{3}$ match well, alkyl nitrates (ANs) and peroxy nitrates (PNs) are overestimated by factors of 2 and 4 respectively. This overestimation of reactive nitrogen species has also been seen in other modeling studies (Brioude et al., 2013; Yu et al., 2012).

To understand whether the overestimate is an emissions issues, chemistry issue, or both, we examined the partitioning of the $\mathrm{NO}_{y}$
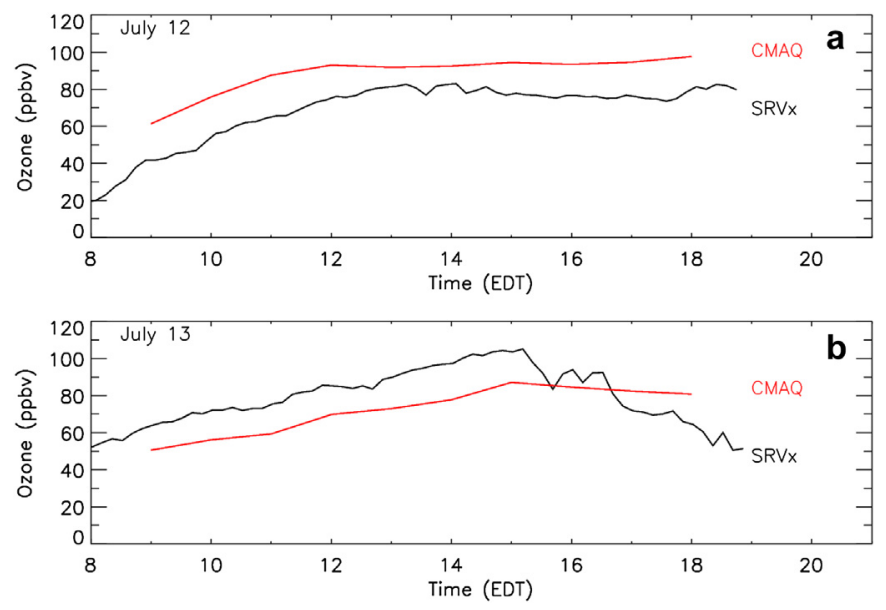

Fig. 7. Ozone concentration (ppbv) as a function of time at the SRVx's location and at the closest CMAQ grid point on a) July 12, 2011 and b) July 13, 2011. species. If partitioning is correct, then the issue is likely due to high emissions or low dispersion rates. To gain insight on this issue, we took the ratio of $\mathrm{NO} / \mathrm{NO}_{y}$ during the morning hours when the two species are positively correlated and the NO measurement is above the detection limit. As seen in Fig. 11, the $\mathrm{NO} / \mathrm{NO}_{y}$ ratios between the model simulation and observations often lie below the 1-to-1 line. The mean of the data shows NO concentrations are $10.0 \%$ of total $\mathrm{NO}_{y}$ in the observations, while NO concentrations are $7.6 \%$ of total $\mathrm{NO}_{y}$ in the CMAQ simulation. This indicates that $\mathrm{CB} 05$, as employed, partitions more $\mathrm{NO}_{y}$ species as higher oxides (i.e., ANs, $\mathrm{PNs}, \mathrm{HNO}_{3}$ ) than is observed. This suggests that gas-phase chemistry scheme (CB05) overestimates the lifetimes of higher order $\mathrm{NO}_{y}$ species such as ANs and PNs, deposition rates are too slow, or conversion rates of $\mathrm{NO}_{y}$ to $\mathrm{NO}_{2}$ are slower than observed.

To minimize computing time, the CB05 chemical mechanism simplifies the alkyl nitrates by grouping all alkyl nitrates in a single chemical species (NTR). The lifetime of NTR calculated during a simulation of CMAQ using 2007 summer conditions, yields a lifetime of 10 days. It has been shown that isopropyl nitrate has a lifetime of 10 days (Luke et al., 1989), but higher-order alkyl nitrates have a much shorter lifetime (1-2 days) (Horowitz et al., 2007; Perring et al., 2009), due to a lack of electronegativity holding the gas phase species together. The shorter lifetimes of the high-order alkyl nitrates species are not accounted for in the CB05 gas-phase chemistry scheme. After decomposition, the alkyl nitrates split into an alkyl chain and $\mathrm{NO}_{2}$. If the lifetime of NTR in $\mathrm{CB} 05$ were to be shorter, then this would yield lower concentrations of alkyl nitrates, which would be more consistent with observations.

To represent peroxy nitrates in the model, the CB05 mechanism simplifies the species into peroxyacyl nitrates (PAN), all other higher order peroxyacyl nitrates (PANX) and peroxynitric acid (PNA), with the latter being a very small fraction of the first two at high temperatures. The sum of the concentrations of peroxy nitrates (PNs) in the model is higher than observed. The primary destruction of peroxyacyl nitrates is via thermal dissociation. At higher temperatures, PAN and PANX dissociate more rapidly into acetylperoxy radicals $\left(\mathrm{CH}_{3} \mathrm{C}(\mathrm{O}) \mathrm{O}_{2}\right)$ and higher order acylperoxy radicals $\left(\mathrm{C}_{2} \mathrm{H}_{5} \mathrm{C}(\mathrm{O}) \mathrm{O}_{2}\right)$ respectively. The concentration of PAN and PANX is therefore governed by the kinetic equilibrium rate constant, which is a function of temperature, and the concentrations of the products, $\mathrm{CH}_{3} \mathrm{C}(\mathrm{O}) \mathrm{O}_{2}, \mathrm{C}_{2} \mathrm{H}_{5} \mathrm{C}(\mathrm{O}) \mathrm{O}_{2}$, and $\mathrm{NO}_{2}$. There are stark differences in the kinetic equilibrium rate constant $\left(K_{\mathrm{EQ}}\right)$ between IUPAC (2010) and JPL (2011), with the latter being 24\% less than the former $\left(3.03 \times 10^{-8}\right.$ vs. $\left.2.3 \times 10^{-8}\right)$ at $298 \mathrm{~K}$. The CB05 mechanism uses the higher IUPAC (2010) kinetic equilibrium rate constant, which favors a higher production rate of PAN. Furthermore, some studies (Turnipseed et al., 2006; Wu et al., 2012) have suggested that the dry deposition rates of PAN in the air quality models are too slow. Updating the rate constants of PAN formation as well as changing the dry deposition velocities, may better align the model output with observations.

\section{Discussion}

The observations from the SRVx show, with a 95\% confidence level certainty, that ozone concentrations are elevated over the Bay when compared to upwind ground sites. The extended period of high ozone causes a larger number of days to exceed the U.S. EPA 8h 75 ppbv NAAQS threshold over the Bay than over nearby land areas. Here we discuss potential reasons for this phenomenon and attempt to apportion a relative importance for each mechanism.

During a day that lacks precipitation, which is the case for most ozone exceedance days in the Baltimore-Washington metropolitan region, ozone is primarily destroyed by the mechanisms listed in Table 5 (Seinfeld and Pandis, 2006). Dry deposition (mechanism 1) 

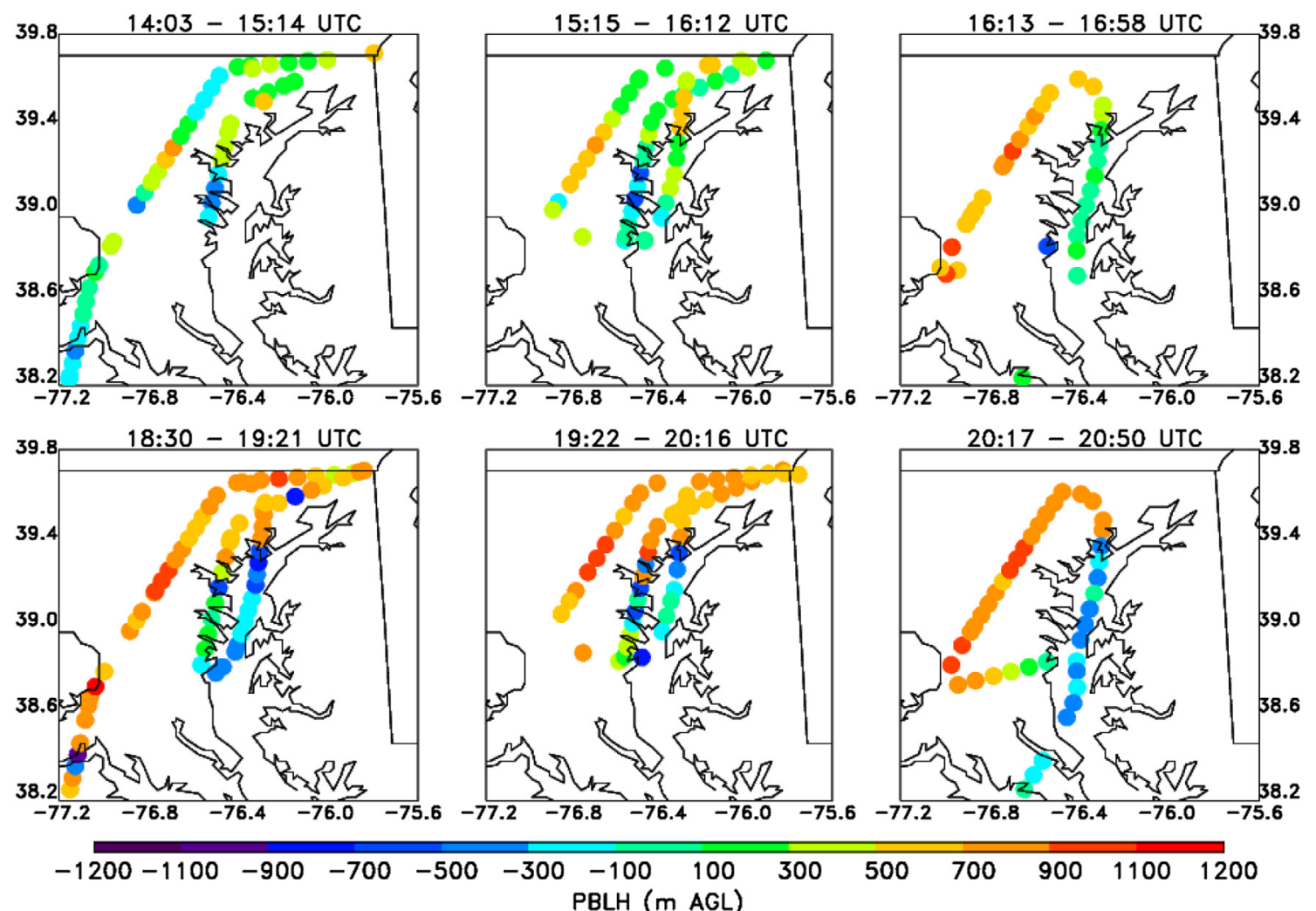

Fig. 8. PBL depth output by WRF minus measurements of boundary layer height using a high spectral resolution lidar (HSRL) aboard the UC-12 aircraft on July 20 , 2011.

is the primary mode of ozone destruction near the surface. Titration due to NO (mechanism 2) also occurs near the surface, but this serves as a reservoir for $\mathrm{O}_{3}$ as $\mathrm{NO}_{2}$ is re-generated. Mechanisms 3-5 are most prominent in the upper troposphere and isolated ocean regions where dry deposition rates are minimal.

Deposition is the primary mode of destruction in the boundary layer and occurs fastest in heavily forested areas (Fowler et al., 2001; Nowak et al., 2006). Differences in ozone dry deposition rates have been widely studied. A list of 24-h-averaged dry

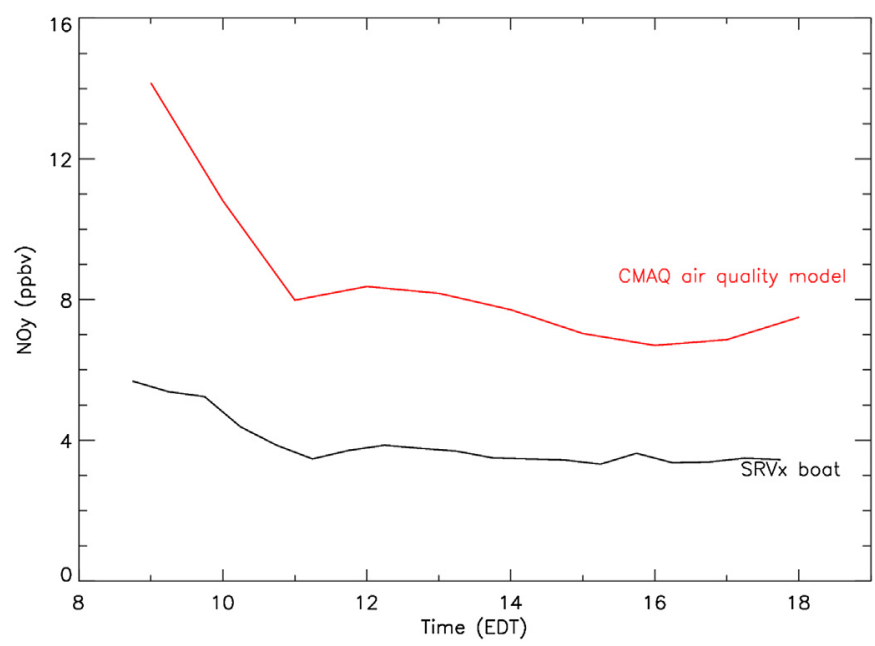

Fig. 9. Total $\mathrm{NO}_{y}$ concentration measured on the $\mathrm{SRV} x$ compared to total $\mathrm{NO}_{y}$ from the closest grid point in CMAQ on July 13, 2011 as a function of time. deposition velocities from the literature is given in Table 6 (Wesely and Hicks, 2000; Chang et al., 2004; Nowak et al., 2006).

For a mix of $50 \%$ deciduous forest, $25 \%$ grass, and $25 \%$ pavement, the 24-h averaged dry deposition velocity for ozone is $0.50 \mathrm{~cm} \mathrm{~s}^{-1}$. However, estimates for dry deposition of ozone in coastal environments are $0.15 \mathrm{~cm} \mathrm{~s}^{-1}$. The slower deposition velocity is due to a lack of vegetation and surface roughness in coastal areas (Gallagher et al., 2001). To calculate the difference in ozone deposition over an hour, we can use the formula described in Table 7. For a boundary layer depth of $800 \mathrm{~m}$, which is typical over the Chesapeake Bay during the mid-afternoon, ozone concentration would be approximately $1.6 \%$ higher after an hour than an air parcel of similar concentration over land due to slower deposition velocities over water, assuming all other environmental conditions are the same.

If winds are from the southwest, maximizing residence time over the Bay, an air parcel that entered the southwest portion of Chesapeake Bay may have been over the Bay for approximately $5 \mathrm{~h}$. By the time an air parcel leaves the Bay, its ozone concentration theoretically could be $8 \%$ higher than transport over land.

Boundary layer height also plays a major role in determining concentrations of ozone near the surface (Rao et al., 2003). Pollutants are primarily confined within the boundary layer due to a strong subsidence inversion during anticyclonic events. The only mechanism by which pollutants can be vented out of the boundary layer during strong anticyclonic setups is through fair-weather cumulus clouds (Dacre et al., 2007). However, cumulus clouds are largely non-existent over the Chesapeake Bay during strong subsidence events (Loughner et al., 2011).

The boundary layer over land tends to be deeper because the surface temperature is higher over land during clear-sky conditions in the mid-afternoon. As the boundary layer depth decreases, emissions of ozone precursors, such as $\mathrm{NO}_{x}$ compounds, 

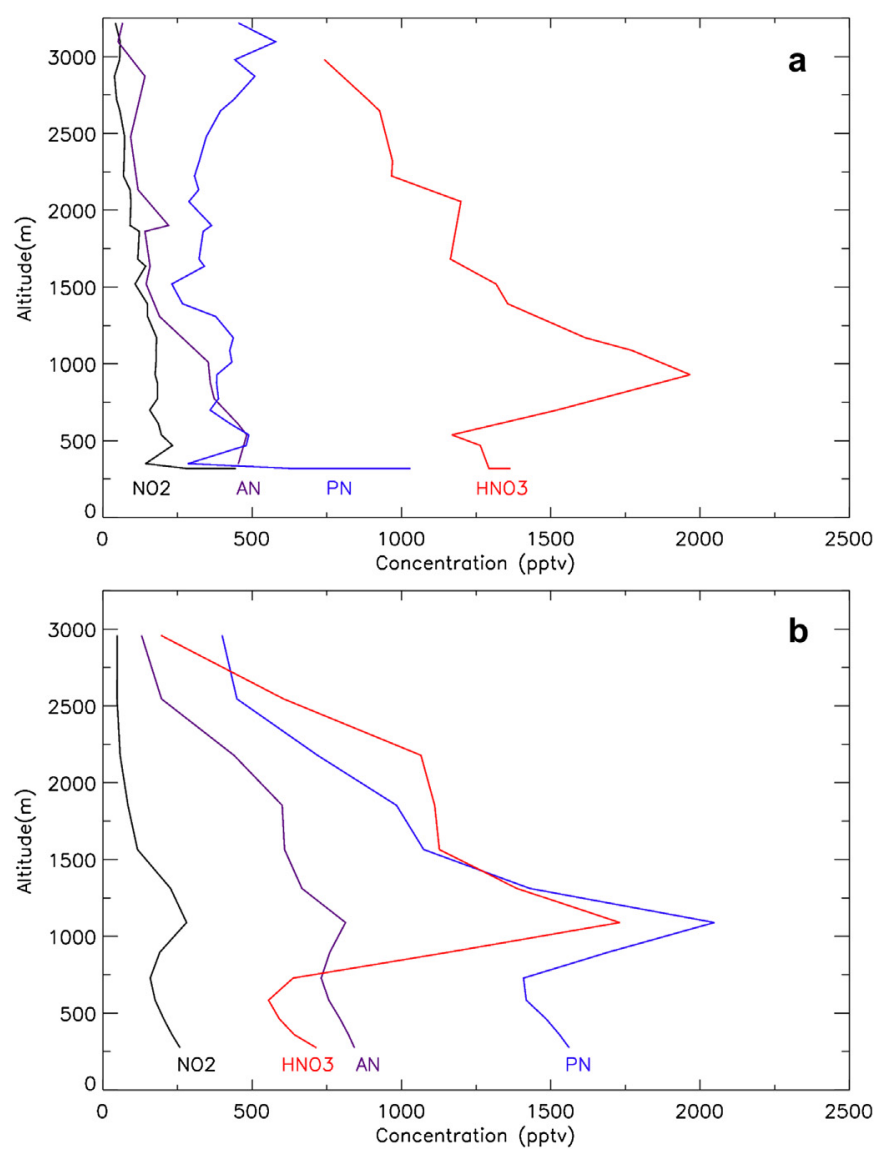

Fig. 10. a. Total $\mathrm{NO}_{y}$ concentration (minus $\left.\mathrm{NO}\right)$ split by compound $\left(\mathrm{NO}_{2}\right.$, peroxy nitrates (PN), alkyl nitrates (AN), and $\mathrm{HNO}_{3}$ measured on the $\mathrm{P} 3-\mathrm{B}$ as function of altitude during the 1630 UTC spiral on July 20, 2011 over the Chesapeake Bay. b. Same as Fig. 10a but using model results from the closest grid point in CMAQ at 1700Z (1 PM local time).

accumulate in a smaller volume of the atmosphere leading to higher concentrations. On July 20 between 20 and 21 UTC or 4 PM and 5 PM local time, the HSRL aboard the UC-12B aircraft measured the aerosol-based boundary layer depth to be 1000-1200 m over land and 400-600 $\mathrm{m}$ over the Chesapeake Bay within $10 \mathrm{~min}$ as

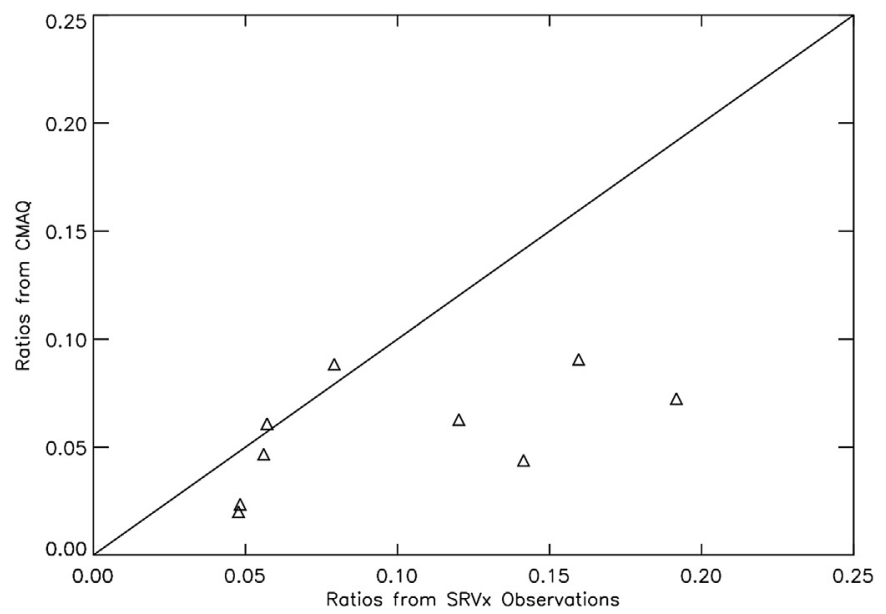

Fig. 11. $\mathrm{NO} / \mathrm{NO}_{y}$ ratios from $1.33 \mathrm{~km} \mathrm{CMAQ}$ run vs. observations from the ship during the morning hours when $\mathrm{NO}$ and $\mathrm{NO}_{y}$ are positively correlated and $\mathrm{NO}$ is above the instrument's detection limit.
Table 5

Loss mechanisms for ozone in the lower troposphere.

\begin{tabular}{ll}
\hline Mechanism 1 & Dry deposition \\
\hline Mechanism 2 & $\mathrm{O}_{3}+\mathrm{NO} \rightarrow \mathrm{O}_{2}+\mathrm{NO}_{2}$ \\
Mechanism 3 & $\mathrm{O}_{3}+\mathrm{OH} \rightarrow \mathrm{O}_{2}+\mathrm{HO}_{2}$ \\
Mechanism 4 & $\mathrm{O}_{3}+\mathrm{HO}_{2} \rightarrow \mathrm{OH}+2 \mathrm{O}_{2}$ \\
Mechanism 5 & $\mathrm{O}_{3}+h \nu \rightarrow \mathrm{O}_{2}+\mathrm{O}\left({ }^{1} \mathrm{D}\right)$ at $h \nu<320 \mathrm{~nm}$ \\
\hline
\end{tabular}

seen in Fig. 12. If there were no boundary layer venting and environmental conditions and emissions were identical, the concentrations of $\mathrm{NO}_{2}$ could be up to a factor of 2 higher over the Bay than over land leading to a substantial increase in $\mathrm{O}_{3}$, since the midAtlantic region is in the $\mathrm{NO}_{x}$-limited regime. However, there is likely some vertical mixing and emissions are likely lower over the Bay. Although there were no direct measurements of $\mathrm{NO}_{2}$ at the surface of the bay during this particular campaign, data on the P3-B shows that at $0.3 \mathrm{~km}$, the lowest altitude of the flight spirals, $\mathrm{NO}_{2}$ is higher by as much as 0.5 ppbv over water than land. Using ozone efficiency rates from the DISCOVER-AQ campaign, for every 1 ppbv increase in $\mathrm{NO}_{x}$, ozone production will increase by an average of $8.26 \mathrm{ppbv}$ with a $90 \%$ confidence interval of $4.93-19.4 \mathrm{ppbv}(\mathrm{He}$ et al., 2013); this is slightly higher than an urban study in Houston, which showed an average ozone production efficiency of 5.9 (Neuman et al., 2009).

A bay-breeze circulation often develops over the Chesapeake Bay during the late spring and early summer (Ryan et al., 1998; Stauffer et al., 2012) impacting the coastal temperature structure and associated meteorological conditions. The bay-breeze yields a meso-high pressure directly over the Chesapeake Bay, and a mesolow pressure just inland from the Bay. This creates stagnation and clear skies directly over the Bay. Fewer cumulus clouds develop over the Chesapeake Bay than over land because of the lower surface temperature, shallower boundary layer depth and relative lack of thermals over the water. Decreased cloud cover increases photolysis rates by allowing more UV radiation to reach the lowest levels of the atmosphere creating an environment more favorable for ozone production. On July 20 , visible satellite imagery, seen in Fig. 13, shows an expanse of low level fair cumulus clouds over the Baltimore-Washington region, with no clouds over the Bay. Cloud coverage is estimated to be $10-30 \%$ over land and $0 \%$ over the Bay leading to a higher $\mathrm{j}\left(\mathrm{NO}_{2}\right)$ value over the Bay.

During the DISCOVER-AQ campaign, the P3-B aircraft measured $\mathrm{j}\left(\mathrm{NO}_{2}\right)$ throughout its flights. In the mid-afternoon, 3:30 PM local time, on July 20, 2011 when the P3-B flew at an altitude of $390 \mathrm{~m}$ over land in an absence of clouds, the $\mathrm{j}\left(\mathrm{NO}_{2}\right)$ rate constant was $0.0082 \mathrm{~s}^{-1}$, while $30 \mathrm{~s}$ later underneath a fair-weather cumulus cloud, which was confirmed by looking at the forward camera on the $\mathrm{P} 3-\mathrm{B}$, the $\mathrm{j}\left(\mathrm{NO}_{2}\right)$ rate constant dropped to $0.0043 \mathrm{~s}^{-1}$. If we assume the sky over land is filled with $20 \%$ cumulus clouds and the sky over the Bay has no clouds, the average $\mathrm{j}\left(\mathrm{NO}_{2}\right)$ would be $0.0074 \mathrm{~s}^{-1}$ over land and $0.0082 \mathrm{~s}^{-1}$ over the Bay. Therefore, dissociation of $\mathrm{NO}_{2}$ into $\mathrm{NO}$ and odd oxygen may be up to $10.5 \%$ faster during the mid-afternoon of a summer day.

It is estimated that $\mathrm{NO}_{x}$ emissions from barges that travel the Chesapeake Bay account for $10 \%$ of all mobile emission sources (U.S.

Table 6

Ozone deposition velocities for various surface types.

\begin{tabular}{llll}
\hline & Forest & Coastal & Ocean \\
\hline Nowak et al. (2006) & $0.5 \mathrm{~cm} \mathrm{~s}^{-1}$ & - & - \\
Wesely and Hicks (2000) & $0.8 \mathrm{~cm} \mathrm{~s}^{-1}$ & - & - \\
Chang et al. (2004) & - & - & $0.05 \mathrm{~cm} \mathrm{~s}^{-1}$ \\
Gallagher et al. (2001) & - & $0.148 \mathrm{~cm} \mathrm{~s}^{-1}$ & - \\
\hline
\end{tabular}


Table 7

Calculation of the difference in ozone dry deposition over land and the bay.

$$
\begin{aligned}
& \frac{V_{\text {d(land })}}{\text { PBL depth }}-\frac{V_{\text {d(bay })}}{\text { PBL depth }} \\
& \frac{18 \mathrm{~m} / \mathrm{h}}{800 \mathrm{~m}}-\frac{5.328 \mathrm{~m} / \mathrm{h}}{800 \mathrm{~m}}=1.58 \mathrm{~h}^{-1}
\end{aligned}
$$

EPA, 2010). In March 2010, the U.S. EPA adopted a regulation requiring large barges to burn cleaner fuel that which emits less $\mathrm{NO}_{x}$ when they are within 200 nautical miles of the North American coastline (U.S. EPA, 2010). However, this regulation was not enforceable by the U.S. EPA until August 2012, which is after the Maryland DISCOVER-AQ field study. Many large transport tankers burn bottom-of-the-barrel bunker fuel, which releases a higher proportion of $\mathrm{NO}_{x}$ than diesel fuel (Eyring et al., 2005). To date, there has been little quantification of barge emissions (Mason et al., 2008 ). Using the 8.26 ppbv $\mathrm{O}_{3}$ per ppbv $\mathrm{NO}_{x}$ ozone production efficiency calculated during the DISCOVER-AQ campaign (He et al., 2013), we estimate that $0.1 \mathrm{ppbv}$ increase in $\mathrm{NO}_{x}$ concentrations over the Chesapeake Bay could yield a $0.8 \mathrm{ppbv}$ increase in ozone, since the mid-Atlantic region is characterized by the $\mathrm{NO}_{x}$-limited regime of ozone production.

Halogen chemistry may play a role in ozone formation over the Chesapeake Bay. Recent modeling studies suggest that $\mathrm{Cl}_{2}$ photochemistry may result in an increase of $5-8 \mathrm{ppbv}$ in daily maximum ozone levels (Finley and Saltzman, 2006). To see if more chlorine is available over the Bay, we looked at the 5-year average (between 2007 and 2011) of $\mathrm{Cl}^{-}$dry and wet deposition at two Clean Air Status and Trends Network (CASTNET) sites in Maryland. The Blackwater National Refuge site is located on Maryland's eastern shore and is generally downwind of the Bay, while the Beltsville site is located upwind of the Bay. Dry deposition rates of $\mathrm{Cl}^{-}$are 2.14 times higher

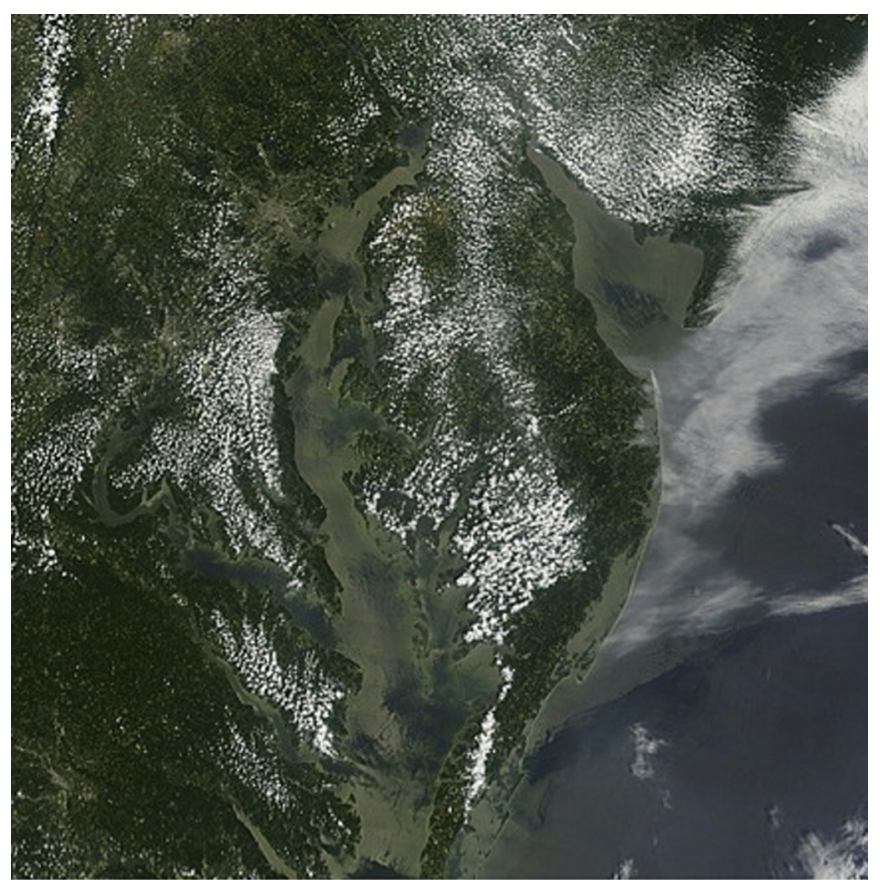

Fig. 13. Visible image from the MODIS satellite at $1610 \mathrm{Z}$ (2:10 PM local time) on July 20,2011 showing the presence of low-level cumulus clouds only over the land.

over a 5-year average at the Blackwater site and wet deposition rates of $\mathrm{Cl}^{-}$are 3.62 times higher.

One factor inhibiting ozone production over the Bay is the lower tropospheric temperature profile. Coastal areas in extratropical
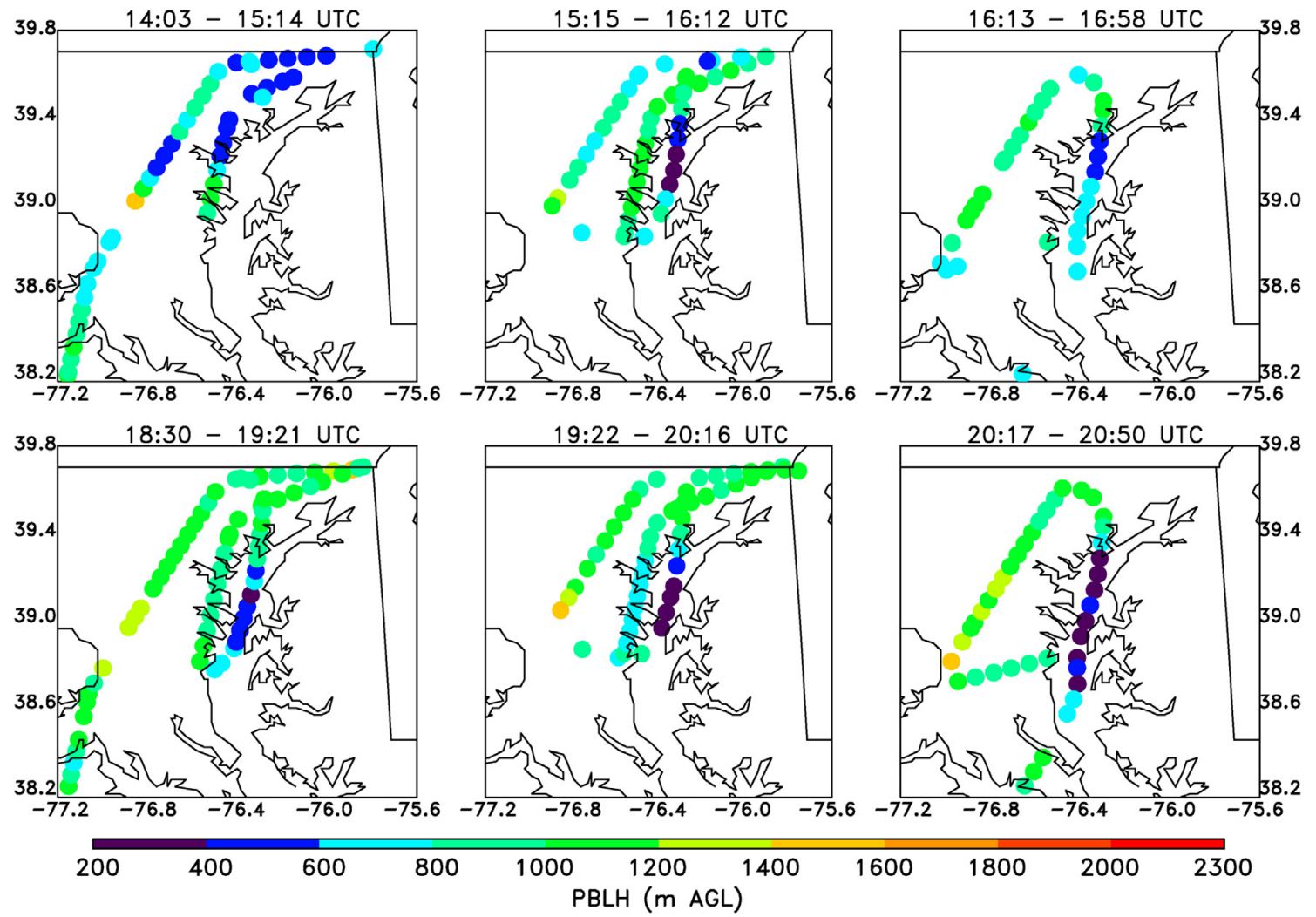

Fig. 12. Measurements of boundary layer height using a high spectral resolution lidar (HSRL) aboard the UC-12 aircraft on July $20,2011$. 
latitudes heat up more slowly than nearby inland locations during the summer due to the influence of the cooler waters. During the 10-day campaign, temperatures on the SRVx at 2 PM local time were on average $3.4^{\circ} \mathrm{C}$ cooler than the Baltimore-Washington International (BWI) airport which is located $30 \mathrm{~km}$ inland from the Chesapeake Bay.

The dissociation of PAN into $\mathrm{NO}_{2}$ has a strong temperature dependence (Seinfeld and Pandis, 2006). A calculation of the rate constant using IUPAC (2010) shows that PAN dissociates 1.66 times quicker at $304.3 \mathrm{~K}$ than $300.9 \mathrm{~K}$. The quicker dissociation of PAN at higher temperatures over land shifts the equilibrium reaction toward $\mathrm{NO}_{2}$, the primary precursor to ozone in the $\mathrm{NO}_{x}$-limited regime over the Mid-Atlantic. However, the dissociation of PAN is slower over the Bay, keeping more $\mathrm{NO}_{2}$ tied up as PAN, and thereby decreasing $\mathrm{O}_{3}$ production.

\section{Conclusions}

Observations from the NOAA SRVx vessel during the DISCOVERAQ and GEO-CAPE CBODAQ campaigns show with a certainty exceeding the 2-sigma level, that daytime ozone concentrations are elevated over the Bay when compared to the closest upwind ground station. We posit that this high anomaly is influenced by a number of mechanisms, in approximate descending order:

- Shallower boundary layers trapping shipping emissions near the surface

- Higher photolysis rates due to clear skies over the bay

- Decreased boundary layer venting due to a lack of fair-weather cumulus clouds

- Slower deposition velocity over the Bay

The ozone concentrations exhibit a high anomaly over the Bay even though temperatures are cooler and allow precursors to ozone such as PAN to remain more stable. The observed high anomaly over the Chesapeake Bay is of primary importance since many citizens spend their leisure time on or near the Chesapeake Bay during the summertime, and are exposed to the unhealthy air quality conditions. Onshore winds can bring these pollutants to local coastal and inland communities. Expanded monitoring of ozone directly over the Chesapeake Bay is needed to precisely quantify the extent of this high anomaly.

\section{Acknowledgments}

This research was supported by the NASA-Air Pollution Over the Eastern US: Integration of AURA/OMI NO2 and SO2, Aircraft, and Ground-Based Observations with Numerical Models grant the MDE Air Pollution in Maryland 2011 grant, and NASA grants NASA.NNX10AQ79G and NASA.NNX11AP07G. The authors would like to thank William Thorn III of NIST for his in situ calibration of the $\mathrm{NO}_{y}$ analyzer, Heather Arkinson, Lacey Brent and Hao He for their help in laboratory calibrations of the analyzers, Ross Salawitch, Tim Canty and Linda Hembeck for their comments and help with model simulations, Antonio Mannino for his tireless organization of the SRVx cruises as part of NASA's GEO-CAPE CBDOAQ oceanographic field campaign, Ronald Cohen and his group at UC-Berkley for their total reactive nitrogen data on-board the P3-B, Chris Hostetler and Rich Ferrare and the HSRL/UC-12B teams for measurements and operations during DISCOVER-AQ, Amy Jo Scarino for the derived mixed layer height values from the HSRL backscatter profiles, John Barrick and Ali Aknan for their $\mathrm{j}\left(\mathrm{NO}_{2}\right)$ data aboard the P3-B aircraft, and Jim Crawford, Gao Chen and Mary Kleb for their work in organizing the DISCOVER-AQ campaign.

\section{Appendix A. Supplementary data}

Supplementary data related to this article can be found at http:// dx.doi.org/10.1016/j.atmosenv.2013.11.008.

\section{References}

Anenberg, S.C., Horowitz, L.W., Tong, D.Q., West, J.J., 2010. An estimate of the global burden of anthropogenic ozone and fine particulate matter on premature human mortality using atmospheric modeling. Environmental Health Perspectives 118 (9), 1189.

Bell, M.L., McDermott, A., Zeger, S.L., Samet, J.M., Dominici, F., 2004. Ozone and short-term mortality in 95 US urban communities, 1987-2000. JAMA: The Journal of the American Medical Association 292 (19), 2372-2378.

Brent, L.C., Thorn, W.J., Gupta, M., Leen, B., Stehr, J.W., He, H., et al., 2013. Evaluation of the use of a commercially available cavity ringdown absorption spectrometer for measuring NO2 in flight, and observations over the Mid-Atlantic States, during DISCOVER-AQ. J. Atmos. Chem..

Brioude, J., Angevine, W.M., Ahmadov, R., Kim, S.-W., Evan, S., et al., 2013. Top-down estimate of surface flux in the Los Angeles Basin using a mesoscale inverse modeling technique: assessing anthropogenic emissions of $\mathrm{CO}, \mathrm{NO}_{x}$ and $\mathrm{CO}_{2}$ and their impacts. Atmos. Chem. Phys. 13, 3661-3677. http://dx.doi.org/ 10.5194/acp-13-3661-2013.

Byun, D., Schere, K.L., 2006. Review of the governing equations, computational algorithms, and other components of the models-3 community multiscale air quality (CMAQ) modeling system. Appl. Mechan. Rev. 59 (1/6), 51.

Castellanos, P., Marufu, L.T., Doddridge, B.G., Taubman, B.F., Schwab, J.J., Hains, J.C., et al., 2011. Ozone, oxides of nitrogen, and carbon monoxide during pollution events over the eastern United States: an evaluation of emissions and vertical mixing. J. Geophys. Res. Atmos. 116. ARTN D16307.

Castellanos, P., Stehr, J.W., Dickerson, R.R., Ehrman, S.H., 2009. The sensitivity of modeled ozone to the temporal distribution of point, area, and mobile source emissions in the eastern United States. Atmos. Environ. 43 (30), 4603-4611.

Chameides, W.L., Fehsenfeld, F., Rodgers, M.O., Cardelino, C., Martinez, J., Parrish, D., et al., 1992. Ozone precursor relationships in the ambient atmosphere. J. Geophys. Res. Atmosph. (1984-2012) 97 (D5), 6037-6055.

Chang, W., Heikes, B.G., Lee, M., 2004. Ozone deposition to the sea surface: chemical enhancement and wind speed dependence. Atmos Environ 38 (7), 1053-1059.

Crawford, J.H., Pickering, K.E., 2011. DISCOVER-AQ observations over the BaltimoreDC area during July 2011. In: Proceedings from American Geophysical Union, Fall Meeting 2011, San Francisco, CA.

Dacre, H.F., Gray, S.L., Belcher, S.E., 2007. A case study of boundary layer ventilation by convection and coastal processes. J. Geophys. Res. 112 (D17), D17106.

Day, D.A., Wooldridge, P.J., Dillon, M.B., Thornton, J.A., Cohen, R.C., 2002. A thermal dissociation laser-induced fluorescence instrument for in situ detection of $\mathrm{NO2}$ peroxy nitrates, alkyl nitrates, and $\mathrm{HNO}_{3}$. J. Geophys. Res. Atmos. 107 (D5-6). ARTN 4046.

Delany, A.C., Melchior, F.L., Wartburg, A.F., 1982. Modification of a commerical $\mathrm{NO}_{x}$ detector for high sensitivity. Rev. Sci. Instrum. 53 (12), 1899-1902.

Draxler, R.R., Rolph, G.D., 2003. HYSPLIT (HYbrid Single-particle Lagrangian Integrated Trajectory) Model. NOAA Air Resources Laboratory, Silver Spring, MD. Access via NOAA ARL READY Website http://www.arl.noaa.gov/ready/hysplit4. html.

Dye, T.S., Roberts, P.T., Korc, M.E., 1995. Observations of transport processes for ozone and ozone precursors during the 1991 Lake Michigan ozone study. Journal of applied meteorology 34 (8), 1877-1889.

Emmons, L.K., Walters, S., Hess, P.G., Lamarque, J.-F., Pfister, G.G., Fillmore, D., et al., 2010. Description and evaluation of the model for ozone and related chemical tracers, version 4 (MOZART-4). Geosci. Model Develop. 3 (1), 43-67.

EPA, U. S, 2006. (2006 Final). Air Quality Criteria for Ozone and Related Photochemical Oxidants. U.S. Environmental Protection Agency, Washington, DC. EPA/600/R-05/004aF-cF.

EPA U. S, 2008. Air Quality Designations for the 2008 Ozone National Ambient Air Quality Standards. http://www.epa.gov/oaqps001/greenbk/hindex.html.

EPA, U. S, 2010. Control of Emissions From New Marine Compression-Ignition Engines at or Above 30 Liters per Cylinder. http://www.gpo.gov/fdsys/pkg/FR2010-04-30/html/2010-2534.htm.

Eyring, V., Köhler, H.W., Van Aardenne, J., Lauer, A., 2005. Emissions from international shipping: 1. The last 50 years. J. Geophys. Res. Atmos. (1984-2012) 110 (D17).

Fann, N., Lamson, A.D., Anenberg, S.C., Wesson, K., Risley, D., Hubbell, B.J., 2011 Estimating the national public health burden associated with exposure to ambient PM2.5 and ozone. Risk Anal. 32 (1), 81-95.

Finley, B.D., Saltzman, E.S., 2006. Measurement of $\mathrm{Cl} 2$ in coastal urban air. Geophys. Res. Lett. 33 (11), L11809.

Fowler, D., Flechard, C., Cape, J.N., Storeton-West, R.L., Coyle, M., 2001. Measurements of ozone deposition to vegetation quantifying the flux, the stomatal and non-stomatal components. Water Air Soil Pollut. 130 (1-4), 63-74.

Frost, G.J., McKeen, S.A., Trainer, M., Ryerson, T.B., Neuman, J.A., Roberts, J.M., et al. 2006. Effects of changing power plant $\mathrm{NO}_{x}$ emissions on ozone in the eastern United States: proof of concept. J. Geophys. Res. 111 (D12), D21306.

Gallagher, M.W., Beswick, K.M., Coe, H., 2001. Ozone deposition to coastal waters. Quart. J. Royal Meteorolog. Soc. 127 (572), 539-558. 
Godowitch, J.M., Hogrefe, C., Rao, S.T., 2008. Diagnostic analyses of a regional air quality model: changes in modeled processes affecting ozone and chemicaltransport indicators from $\mathrm{NO}_{x}$ point source emission reductions. J. Geophys. Res. Atmos. (1984-2012) 113 (D19).

Grell, G.A., Knoche, R., Peckham, S.E., McKeen, S.A., 2004. Online versus offline air quality modeling on cloud-resolving scales. Geophys. Res. Lett. 31 (16).

Hair, J.W., Hostetler, C.A., Cook, A.L., Harper, D.B., Ferrare, R.A., Mack, T.L., et al. 2008. Airborne high spectral resolution lidar for profiling aerosol optical properties. Appl. Optics 47 (36), 6734-6752.

He, H., Stehr, J.W., Hains, J.C., Krask, D.J., Doddridge, B.G., Vinnikov, K.Y., et al., 2013. Trends in emissions and concentrations of air pollutants in the lower troposphere in the Baltimore/Washington airshed from 1997 to 2011. Atmos. Chem. Phys. Discuss. 13 (2), 3135-3178.

Hintsa, E.J., Allsup, G.P., Eck, C.F., Hosom, D.S., Purcell, M.J., Roberts, A.A., et al., 2004 New ozone measurement systems for autonomous operation on ocean buoys and towers. J. Atmos. Ocean. Technol. 21 (7), 1007-1016.

Horowitz, L.W., Fiore, A.M., Milly, G.P., Cohen, R.C., Perring, A., Wooldridge, P.J., et al., 2007. Observational constraints on the chemistry of isoprene nitrates over the eastern United States. J. Geophys. Res. Atmos. 112 (D12). ARTN D12S08.

Houyoux, M. R., \& Vukovich, J. M, 1999. Updates to the sparse matrix operator kernel emissions (SMOKE) modeling system and integration with Models-3. The Emission Inventory: Regional Strategies for the Future, 1461.

Kleinman, L.I., Daum, P.H., Imre, D.G., Lee, J.H., Lee, Y.-N., Nunnermacker, L.J., et al., 2000. Ozone production in the New York City urban plume. J. Geophys. Res. 105 (D11), 14495-14511.

Kota, S.H., Ying, Q., Schade, G.W., 2012. MOVES Vs. MOBILE6. 2: Differences in Emission Factors and Regional Air Quality Predictions.

Levy, I., Makar, P.A., Sills, D., Zhang, J., Hayden, K.L., Mihele, C., et al., 2010. Unraveling the complex local-scale flows influencing ozone patterns in the southern Great Lakes of North America. Atmospheric Chemistry and Physics 10 (22), $10895-10915$.

Loughner, C.P., Allen, D.J., Pickering, K.E., Zhang, D.L., Shou, Y.X., Dickerson, R.R., 2011. Impact of fair-weather cumulus clouds and the Chesapeake Bay breeze on pollutant transport and transformation. Atmos. Environ. 45 (24), 40604072.

Luke, W.T., Dickerson, R.R., Nunnermacker, L.J., 1989. Direct measurements of the photolysis rate coefficients and Henry's law constants of several alkyl nitrates. J. Geophys. Res. 94 (D12), 14905-14921.

Luria, M., Boatman, J.F., Wellman, D.L., Gunter, R.L., Watkins, B.A., Wilkison, S.W., et al., 1992. Lake Michigan ozone study (LMOS): measurements from an instrumented aircraft. Atmos. Environ. Part A. Gen. Top. 26 (18), 3265-3277.

Mason, R., Dolwick, P., Carey, P., Kinnee, E., Wilson, M., 2008. Emissions processing and sensitivity air quality modeling of category 3 commercial marine vessel emissions. In: Proceedings from 17th Annual International Emission Inventory Conference, Portland, OR.

Neuman, J.A., Nowak, J.B., Zheng, W., Flocke, F., Ryerson, T.B., Trainer, M., et al., 2009. Relationship between photochemical ozone production and $\mathrm{NO}_{x}$ oxidation in Houston, Texas. J. Geophys. Res. Atmos. (1984-2012) 114 (D7).

Nowak, D.J., Crane, D.E., Stevens, J.C., 2006. Air pollution removal by urban trees and shrubs in the United States. Urban Forest. Urban Green. 4 (3), 115-123.
Otte, T.L., Pleim, J.E., 2010. The meteorology-chemistry interface processor (MCIP) for the CMAQ modeling system: updates through MCIPv3. 4.1. Geosci. Model Develop. 3 (1), 243-256.

Perring, A.E., Bertram, T.H., Wooldridge, P.J., Fried, A., Heikes, B.G., Dibb, J., et al., 2009. Airborne observations of total RONO2: new constraints on the yield and lifetime of isoprene nitrates. Atmos. Chem. Phys. 9, 1451-1463.

Rao, S.T., Ku, J.Y., Berman, S., Zhang, K., Mao, H., 2003. Summertime characteristics of the atmospheric boundary layer and relationships to ozone levels over the eastern United States. Pure Appl. Geophys. 160 (1), 21-55.

Ryan, W.F., Doddridge, B.G., Dickerson, R.R., Morales, R.M., Hallock, K.A., Roberts, P.T., et al., 1998. Pollutant transport during a regional $\mathrm{O}_{3}$ episode in the mid-Atlantic states. J. Air Waste Manage. Assoc. 48 (9), 786-797.

Scarino, A.J., Obland, M.D., Fast, J.D., Burton, S.P., Ferrare, R.A., Hostetler, C.A., Berg, L.K. Lefer, B., Haman, C., Hair, J.W., Rogers, R.R., Butler, C., Cook, A.L., Harper, D.B., 2013. Comparison of mixed layer heights from Airborne high spectral resolution lidar, ground-based measurements, and the WRF-Chem model during CalNex and CARES. Atmos. Chem. Phys. Disc. submitted for publication. ISBN: 978-0-47172018-8.

Seinfeld, J.H., Pandis, S.N., 2006. Atmospheric Chemistry and Physics - From Air Pollution to Climate Change, second ed. John Wiley \& Sons.

Skamarock, W.C., Klemp, J.B., Dudhia, J., Gill, D.O., Barker, D.M., Wang, W., et al., 2008. A Description of the Advanced WRF Version 3. NCAR technical note NCAR/TN/u2013475+ STR.

Stauffer, R.M., Thompson, A.M., Martins, D.K., Clark, R.D., Goldberg, D.L., et al., 2012. Bay breeze influence on surface ozone at Edgewood, MD during July 2011. Journal of Atmospheric Chemistry.

Trainer, M., Parrish, D.D., Buhr, M.P., Norton, R.B., Fehsenfeld, F.C., Anlauf, K.G., et al., 1993. Correlation of ozone with $\mathrm{NO}_{y}$ in photochemically aged air. J. Geophys. Res. Atmos. (1984-2012) 98 (D2), 2917-2925.

Turnipseed, A.A., Huey, L.G., Nemitz, E., Stickel, R., Higgs, J., Tanner, D.J., et al., 2006. Eddy covariance fluxes of peroxyacetyl nitrates (PANs) and NOy to a coniferous forest. J. Geophys. Res. 111 (D9), D09304.

Tzortziou, M., Herman, J.R., Cede, A., Loughner, C.P., 2013. Spatial and temporal variability of ozone and nitrogen dioxide over a major urban estuarine ecosystem. J. Atmos. Chem..

Wesely, M.L., Hicks, B.B., 2000. A review of the current status of knowledge on dry deposition. Atmos. Environ. 34 (12), 2261-2282.

Wu, Z., Wang, X., Turnipseed, A.A., Chen, F., Zhang, L., Guenther, A.B., et al., 2012. Evaluation and improvements of two community models in simulating dry deposition velocities for peroxyacetyl nitrate (PAN) over a coniferous forest. J. Geophys. Res. Atmos. (1984-2012) 117 (D4).

Yarwood, G., Rao, S., Yocke, M., Whitten, G., 2005. Updates to the Carbon Bond Chemical Mechanism: CB05. Final report to the US EPA, RT-0400675, 8.

Yegorova, E.A., Allen, D.J., Loughner, C.P., Pickering, K.E., Dickerson, R.R., 2011. Characterization of an eastern US severe air pollution episode using WRF/Chem. J. Geophys. Res. Atmos. 116. ARTN D17306.

Yu, S., Mathur, R., Pleim, J., Pouliot, G., Wong, D., Eder, B., et al., 2012. Comparative evaluation of the impact of WRF/NMM and WRF/ARW meteorology on CMAQ simulations for PM2. 5 and its related precursors during the 2006 TexAQS/ GoMACCS study. Atmos. Chem. Phys. 12, 4091-4106. 